\title{
PERANCANGAN ALAT UJI DEFLEKSI BATANG KANTILEVER FLEKSIBEL
}

\author{
Ferli Adinata ${ }^{1}$, Asnawi Lubis ${ }^{2}$, Anang Ansyori ${ }^{3}$, Tumpal Ojahan $\mathbf{R}^{4}$ \\ ${ }^{1}$ Jurusan Teknik Mesin, Fakultas Teknik, Universitas Malahayati Bandar Lampung \\ Email:ferliadinata123@gmail.com, \\ ${ }^{2}$ Jurusan Teknik Mesin, Fakultas Teknik, Universitas Lampung, Lampung \\ Email: asnawi.lubis@eng.unila.ac.id \\ ${ }^{3}$ Jurusan Teknik Mesin, Fakultas Teknik, Universitas Malahayati Bandar Lampung \\ Email: aanangansyori@yahoo.co.id, \\ ${ }^{4}$ Jurusan Teknik Mesin, Fakultas Teknik, Universitas Malahayati Bandar Lampung \\ Email:tumpal_ojahan@yahoo.com
}

\begin{abstract}
Deflection is the change in shape experienced by the beam in the y direction due to the vertical loading applied to the beam or bar. Cantilever rods are if one end of the beam/rod is clamped and the other end is free. In this study, a flexible cantilever rod deflection test device was designed. This tool is used to determine the deflection/deflection that occurs in the beam/strip plate after being given a load. The method used is library research, a data collection method that is carried out by reading, studying, and researching the relevant literature with the title of this thesis which aims to collect data and analyze a theoretical understanding. This research will focus on designing and testing flexible cantilever rod deflection test equipment and utilizing beam/ strip plate as a test specimen for flexible cantilever rods. This tool has a height of $100 \mathrm{~cm}$ and a width of $90 \mathrm{~cm}$ and this tool is equipped with an HC-SR04 sensor which is directly connected to a digital number. The results of testing the strip plate with a load of $1 \mathrm{~kg}$ and $1.5 \mathrm{~kg}$ using the HC-SRO4 sensor showed that the deflection at the smallest end was $20 \mathrm{~mm}$, and the largest value was $30 \mathrm{~mm}$. the theoretical calculation with equation (2-9) obtained the smallest result of $1.06 \mathrm{~mm}$ and the largest value of $3.5 \mathrm{~mm}$.
\end{abstract}

Keywords: Deflection Test, Cantilever Rod, Sensor HC-SRO4

\begin{abstract}
ABSTRAK
Defleksi adalah perubahan bentuk yang dialami balok pada arah y akibat adanya pembebanan vertikal yang diberikan terhadap balok atau batang. Batang kantilever yaitu jika salah satu ujung balok/batang dijepit dan yang ujung lain bebas. Pada penelitian ini dirancang sebuah alat uji defleksi batang kantilever fleksibel alat ini difungsikan untuk menentukan lendutan/defleksi yang terjadi pada beam/plat strip setelah diberi beban. Metode yang digunakan yaitu dengan penelitian kepustakaan suatu metode pengumpulan data yang dilakukan secara membaca, mempelajari, dan meneliti literature-literature yang relevan dengan judul skripsi ini yang bertujuan untuk mengumpulkan data dan menganalisa suatu pengertian yang bersifat teoritis. Pada penelitian ini akan berfokus pada perancangan dan uji coba alat uji defleksi batang kantilever fleksibel dan memanfaatkan beam/plat strip sebagai bahan spesimen uji batang kantilever fleksibel. Alat ini mempunyai tinggi $100 \mathrm{~cm}$ dan lebar $90 \mathrm{~cm}$ dan alat ini dilengkapi dengan sensor HC-SR04 yang langsung terhubung dengan digital number. Hasil pengujian plat strip beban $1 \mathrm{~kg}$, dan $1.5 \mathrm{~kg}$ menggunakan sensor HC-SR04 didapatkan hasil defleksi pada ujung yang terkecil yaitu 20 $\mathrm{mm}$, dan pada nilai yang terbesar $30 \mathrm{~mm}$. pada perhitungan secara teoritis dengan persamaan (2-9) didapatkan hasil terkecil $1.06 \mathrm{~mm}$ dan nilai yang terbesar $3.5 \mathrm{~mm}$.
\end{abstract}

Kata Kunci: Uji Defleksi, Batang Kantilever, Sensor HC-SR04

\section{PENDAHULUAN \\ Latar Belakang}

Pengujian defleksi sangat penting dilakukan pada material untuk mengetahui kelenturan benda uji ketika terjadi suatu pembebanan. Defleksi/kelenturan merupakan salah satu faktor penting dalam suatu perancangan kontruksi mesin maupun bangunan, untuk mendapatkan kontruksi yang kokoh dan mampu menerima beban yang sesuai dengan rancangan. Dalam perancangan kontruksi salah satu bagian yang perlu diperhatikan yaitu perhitungan defleksi/lendutan dan tegangan pada elemen-elemen ketika mengalami suatu pembebanan. Hal ini sangat penting diperhatikan dari segi kekakuan (stiffnes) dan kekuatan (strength), dimana pada batang 
horizontal yang diberi beban secara lateral akan terjadi defleksi. Defleksi dan tegangan yang terjadi pada elemen-elemen yang mengalami pembebanan harus sesuai pada suatu batas yang diijinkan, karena jika melewati batas yang diijinkan maka akan terjadi kerusakan pada elemenelemen tersebut ataupun pada elemen-elemen lainnya. Dalam kehidupan sehari-hari fenomena defleksi sudah banyak dijumpai seperti pada jembatan atau pada rangka mesin, jika defleksi yang diterima oleh suatu material sangat besar maka akan mempengaruhi safety dari pengguna dan kemampuan rangka dalam menerima tekanan tertentu pada posisi tertentu. Maka dari itu dalam penelitian ini akan dilakukan perbandingan antara hasil perhitungan dengan hasil percobaan sehingga dalam merancang suatu alat akan dapat digunakan dalam rentan waktu yang lama serta mempunyai kekuatan yang besar.

\section{Rumusan Masalah}

Berdasarkan latar belakang dan identifikasi masalah yang telah diuraikan di atas, maka dalam penulisan skripsi ini dapat dirumuskan masalah sebagai berikut:

1. Merancang dan menentukan bentuk alat uji defleksi batang kantilever fleksibel

2. Menghitung ukuran untuk pembuatan alat uji defleksi batang kantilever fleksibel

3. Menetukan defleksi yang terjadi pada spesimen uji secara eksperimental

\section{METODE PENELITIAN}

Pada penelitian ini berfokus pada perancangan dan uji coba alat uji defleksi batang kantilever. Proses perancangan ini dapat dilakukan dengan cara melakukan pemilihan bahan dan komponen yang akan digunakan, serta mempelajari karakteristik dan data fisik, membuat rangkaian dengan melihat fungsi-fungsi komponen yang dipelajari sehingga dapat membuat alat yang sesuai pada spesifikasi yang diharapkan. Dan pada penelitian ini digunakan juga sensor jarak yang bisa mengetahui jarak defleksi batang lentur yaitu HC-SR04.

\section{Desain}

Pada penelitian ini akan berfokus pada perancangan dan uji coba alat uji defleksi batang kantilever dan memanfaatkan beam/plat strip sebagai bahan spesimen uji batang kantilever fleksibel. Alat ini mempunyai tinggi $100 \mathrm{~cm}$ dan lebar $90 \mathrm{~cm}$ dan alat ini dilengkapi dengan sensor HC-SR04 yang langsung terhubung dengan digital number. Detail rancangan dapat dilihat pada Gambar 1.

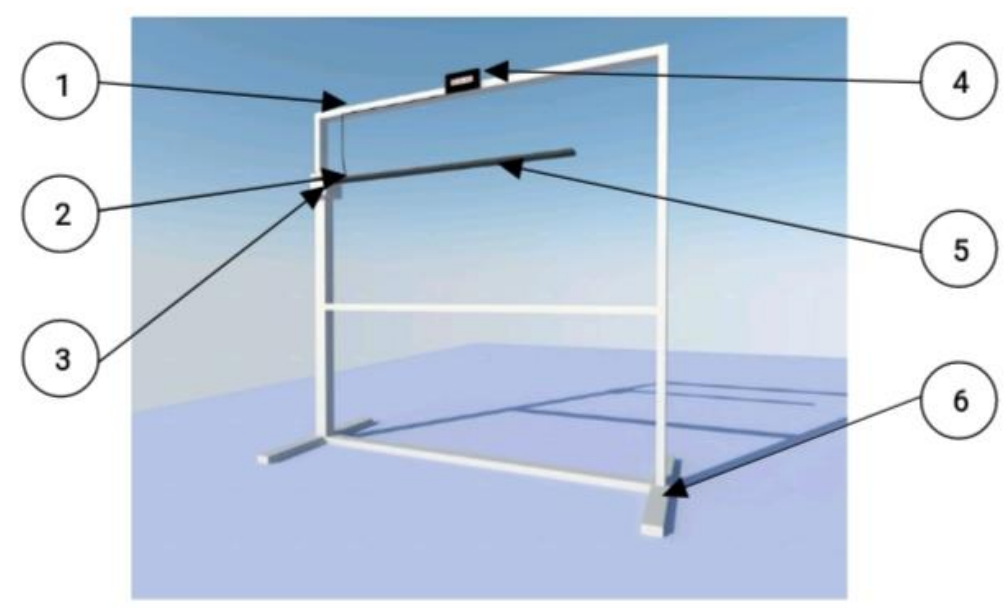

Gambar 1. Desain alat uji defleksi (Agustus, 2020) 


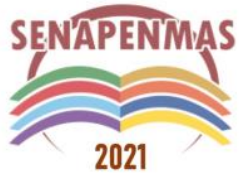

2021
Seminar Nasional Hasil Penelitian dan Pengabdian Kepada Masyarakat 2021 Pengembangan Ekonomi Bangsa Melalui Inovasi Digital Hasil Penelitian dan Pengabdian Kepada Masyarakat Jakarta, 21 Oktober 2021

Keterangan Gambar 1.

1. Kerangka

2. Sensor HC-SR04

3. Tumpuan penjepit spesimen
4. Digital monitor number

5. Plat besi baja

6. Kaki kaki

\section{Prosedur pengujian}

Adapun tata cara melakukan pengujian defleksi batang kantilever fleksibel sebagai berikut:

1. Mempersiapkan semua alat dan bahan untuk pengujian

2. Memasan beam/plat strip dengan variasi tumpuan yang telah ditentukan

3. Memasang beban sesuai posisi P (beban)

4. Melihat nilai defleksi yang terjadi pada sensor

5. Menghitung defleksi pada masing-masing pembebanan

6. Mengulangi langkah 1-4 dengan variasi tumpuan dan beban yang berbeda

7. Mencatat hasil pada table data percobaan

\section{HASIL DAN PEMBAHASAN}

Adapun alat pendukung uji defleksi ialah:

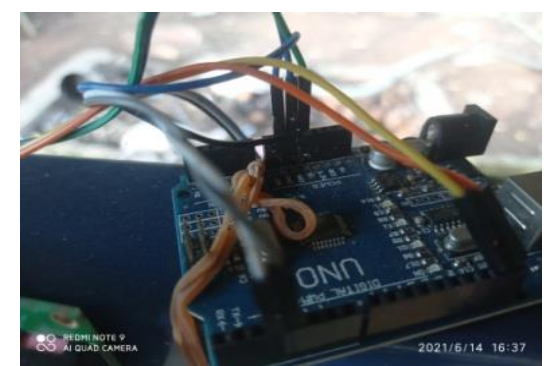

Gambar 2. Arduino (April, 2021)

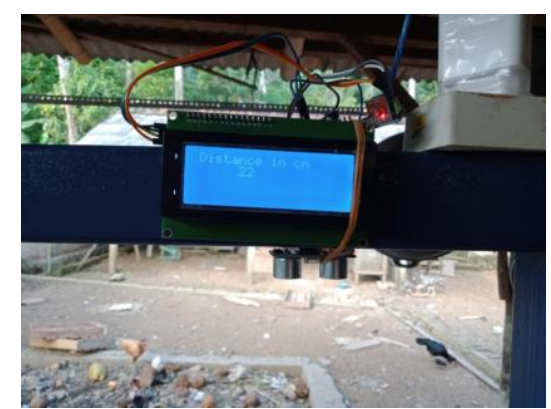

Gambar 3. LCD (April, 2021)

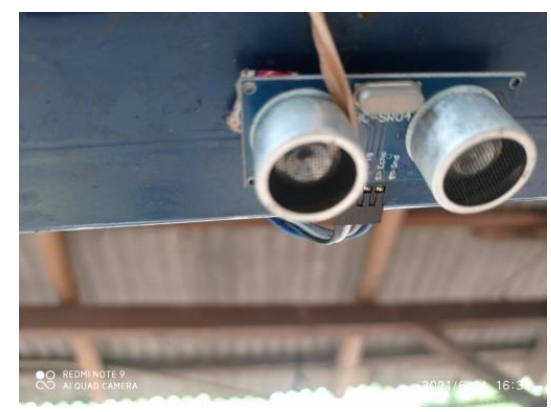

Gambar 4. Sensor HC SR04 (April, 2021) 


\section{Data hasil pengujian}

Selanjutnya dilakukan pengujian dengan beban yang sama dan tumpuan yang sama untuk mencari defleksi yang terjadi setelah pembebanan menggunakan sensor jarak arduino yang sudah dipasang pada kerangka alat uji kemudian mendapatkan hasil seperti pada table 1 .

Tabel 1. Data hasil pengujian sensor jarak arduino

\begin{tabular}{llll}
\hline No & Jenis pembebanan & Beban $(\mathrm{kg})$ & Hasil defleksi $(\mathrm{mm})$ \\
\hline 1 & Beban terpusat di ujung spesimen & 1 & 20 \\
\hline 2 & Beban terpusat di tengah spesimen & 1 & 20 \\
\hline 3 & Beban terpusat di ujung spesimen & 1.5 & 30 \\
\hline 4 & Beban terpusat di tengah spesimen & 1.5 & 20 \\
\hline
\end{tabular}

Setelah melakukan pengujian dan mendapatkan hasil seperti Tabel 1 lalu dilakukan perhitungan secara teoritis untuk mengetahui selisih antara hasil pengujian dengan sensor yang didapat dan perhitungan. Berikut ini adalah penjabaran perhitungan secara teoritis adalah sebagai berikut:

\section{Pembahasan}

Adapun pembahasan berdasarkan hasil percobaaan uji defleksi menggunakan sensor jarak dan perhitungan defleksi di atas ialah:

Table 2 hasil sensor dan perhitungan secara teoritis

\begin{tabular}{lllll}
\hline \multirow{2}{*}{ No } & Jenis pembebanan & \multirow{2}{*}{$\begin{array}{l}\text { Beban } \\
(\mathrm{kg})\end{array}$} & & \multicolumn{2}{l}{ Hasil defleksi $(\mathrm{mm})$} \\
\cline { 5 - 5 } & & sensor & perhitungan \\
\hline 1 & Beban terpusat di ujung spesimen & 1 & 20 & 1.06 \\
\hline 2 & Beban terpusat di tengah spesimen & 1 & 20 & 2.8 \\
\hline 3 & Beban terpusat di ujung spesimen & 1.5 & 30 & 1.59 \\
\hline 4 & Beban terpusat di tengah spesimen & 1.5 & 20 & 3.5 \\
\hline
\end{tabular}

Dari hasil data pengujian mengguanakan sensor di atas didapatkan hasil defleksi pada yang terkecil yaitu $20 \mathrm{~mm}$ sedangkan pada perhitungan secara teoritis dengan persamaan (2-9) didapatkan hasil terkecil 1,06 mm. Dapat dilihat bahwa hasil sensor dan perhitungan berbeda dan terjadi selisih 18,94 $\mathrm{mm}$ pada hasil defleksi yang terkecil.

Dari hasil data pengujian menggunakan sensor di atas didapatkan hasil defleksi pada yang terbesar yaitu $30 \mathrm{~mm}$ sedangkan pada perhitungan dengan persamaan (2-9) secara teoritis didapatkan hasil terbesar 3,5 mm. Dapat dilihat bahwa hasil sensor dan perhitungan berbeda dan terjadi selisih $26,5 \mathrm{~mm}$.

\section{KESIMPULAN DAN SARAN}

\section{Kesimpulan}

Adapun kesimpulan pada perancangan alat uji defleksi batang kantilever fleksibel sebagai berikut:

1. Setelah didapatkan defleksi hasil pengukuran dan perhitungan pada beam dengan 2 jenis pembebanan yaitu terpusat diujung dan ditengah dan 2 jenis beban. Perbedaan defleksi hasil 


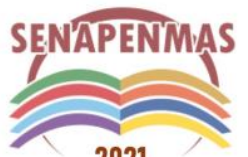

2021
Seminar Nasional Hasil Penelitian dan Pengabdian Kepada Masyarakat 2021 Pengembangan Ekonomi Bangsa Melalui Inovasi Digital Hasil Penelitian dan Pengabdian Kepada Masyarakat Jakarta, 21 Oktober 2021

pengukuran dan perhitungan dengan teori small deflection cukup besar. Dapat disimpulkan bawa teori defleksi kecil tidak akurat untuk menentukan defleksi kantilever fleksibel.

2. Alat uji defleksi batang kantilever dengan tinggin $100 \mathrm{~cm}$ dan lebar $90 \mathrm{~cm}$ berfungsi untuk mengetahui berapa besar defleksi pada beam yang terjadi setelah pembebanan. Dan alat ini sudah dilengkapi dengan sensor HC-SR04 yang sudah diprogramkan ke arduino dan LCD. Sensor berfungsi untuk memudahkan pengujian mendapatkan nilai defleksi pada beam, karna sudah tidak melakukan pengukuran secara manual, dan nilai defleksi akan muncul otomatis dilayar LCD. Ketelitian sensor HC-SR04 hanya membaca nilai $\mathrm{cm}$, dan tidak bisa untuk membaca nilai dengan ketelitian mm.

\section{Saran}

Adapun saran dalam penelitian ini ialah :

1. Pengembangan sangat diperlukan dalam penelitian ini, maka penulis menyaran kan untuk sebaiknya dilakukan penambahan penambahan sensor agar lebih baik kedepannya pada alat penelitian ini.

2. Pada penelitian selanjutnya sebaiknya pengujian dilakukan tidak hanya pada variasi beban tetapi pada variasi spesimen uji.

\section{Ucapan Terima Kasih (Acknowledgement)}

Disini penulis mengucapkan terimakasih kepada universitas malahayati yang telah memberikan kesempatan untuk melakukan penelitian. Dan tidak lupa saya ucapkan terimakasih kepada dosen-dosen strata 1 di fakultas teknik khususnya teknik mesin yang secara cermat telah tulus mendidik, membina serta membekali pengetahuan dan keilmuan penulis. Kedua orang tua yang selalu mendo'akan, memberikan dukungan moril dan materil kepada penulis.

\section{REFERENSI}

Abdie, S., (2012), Diktat Jenis Tumpuan, Kontruksi dan Pembebanan Universitas Dharma Persada, Jakarta.

Ajjie, S., (2016). Buku Mudah Belajar Mikrokontroller Dengan Arduino. https://www.academia.edu/11472322/Buku_mudah_belajar_mikrokontroller_dengan_ardui no. (Diakses 20 april 2021)

Asyari, D. Y., (2010), Diktat Mekanika Kekuatan Material, Universitas Dharma Persada, Jakarta.

Bakshi, U. A. dan M. V. Bakshi. (2008). D.C. Machines and Transformes 1 st edition. Technical publications Pune: India.

B. gustomo. (2015). Pengenalan Arduino Dan Pemrogramannya, Bandung : Informatika Bandung.

Buku panduan penulisan Fakultas Teknik Universitas Malahayati Bandar Lampung, Pedoman Penulisan.

Gere, J. M., dan Timoshenko, S. P., (1997), MEKANIKA BAHAN, Edisi Kedua Versi SI, Jilid I , Erlangga, Jakarta

Ghali, A., M. Neville, A. (1997), Analisa Struktur Gabungan Metode Klasik dan Matriks. Erlangga, Jakarta

Giancoli, D. C., (2001), Fisika Jilid I (Terjemahan). Penerbit Erlangga, Jakarta.

Hikam, M. Dkk., (2005), Eksperimen Fisika Dasar Untuk Perguruan Tinggi, Jakarta, Kencana. 
Munandar,

A

(2012).

Liquid

Crystal

2021 http://www.leselektronika.com/2012/06/liguid-crystal-display-lcd-16-x-2.html. (Diakses 20 april 2021)

Mustopa, (2007), Analisis Teoritis dan Eksperimental Lendutan Pada Batang Balok Sediempat Dengan Variasi Tumpuan, Universitas Tadulako, Palu.

Nugraha. K. F., (2016). Tugas Sensor Ultrasonic HC-SR04, Makalah, Teknik Elektro, Makasar. Popov, E.P., Zainul Astamar, (1993), Mekanika Teknik (Terjemahan). Penerbit Erlangga, Jakarta

Singer, F. L., dan Andrew, P., Darwin Sebayang, (1995). Ilmu Kekuatan Bahan (Terjemahan). Penerbit Erlangga, Jakarta. 